\title{
Preclinical, Pharmacological And Toxicological Studies Of Karpoora Chindhamani Mathirai (KCM) For Analgesic, Anti Inflammatory, Antipyretic Effects In Rats
}

\author{
Research Article
}

\section{Meena $\mathbf{R}^{1 *}$, Ramaswamy $\mathbf{R S}^{2}$}

1. Ph.D Scholar, 2. Professor and Head, Sirappu Maruthuvam Department, National Institute of Siddha, Chennai-47.

\begin{abstract}
Siddha system of medicine is indigenous to India. The drug Karpoora Chindhamani Mathirai chosen from classic Siddha text is subjected to preclinical toxicity studies and for analgesic, anti-inflammatory and antipyretic effects in rats. These preclinical studies are performed to bring a strong evidence based support on the traditional medicine. Toxicity studies are performed as per OECD guidelines and Karpoora Chindhamani Mathirai at the dose of $2000 \mathrm{mg} / \mathrm{kg} /$ po did not exhibit any mortality in rats. Karpoora Chindhamani Mathirai exhibited significant anti inflammatory activity in both carrageenin induced hind paw and cotton pellet granuloma model in rats. The results are comparable to Diclofenac sodium $(5 \mathrm{gm} / \mathrm{kg} / \mathrm{po})$. Karpoora Chindhamani Mathirai also exhibited significant antipyretic and analgesic activity .
\end{abstract}

Key words: Karpoora Chindhamani Mathirai, Rheumatoid arthritis, anti-inflammatory, antipyretic, analgesic.

\section{Introduction:}

Rheumatoid arthritis is an autoimmune disease that can cause chronic inflammation of the joints and other areas of the body (1). It can be correlated to Utiravathasuronitham / Mudakku vatham in Siddha literature (2). This is one of the vatha diseases mentioned by Sage Yugi. Rheumatoid arthritis is a chronic disease, characterized by periods of disease flares and remissions.

RA is a common chronic disease in developed countries (3). 8\%-9\% (70-80 million approximately) of the adult population suffer from some of the other form of rheumatic disease and about 5\%-

*Corresponding author:

\section{Meena $\mathbf{R}$}

Ph.D Scholar,

National Institute of Siddha,

Chennai-47.

Email : meena_r83@yahoo.com,

Mobile No: +91 9444088634.
$6 \%$ of the population has real joint or related disease (i.e, approximately 50million population). Inflammation plays a major role in most chronic illness, including neurodegenerative, cardiovascular, pulmonary, metabolic, autoimmune and neoplastic disease. Inflammatory arthritides were also found in large number of patients (about 1\%-5\% i.e, 10million people with these disorders in India (4). Ayurvedic medicine can treat arthritis and need further scientific exploration.

The WHO estimates that around $80 \%$ of the world population in developing countries relies on traditional plant medicine for primary health care needs (5). Karpoora Chindhamani Mathirai, chosen from a classic siddha text Anuboga Vaidhya Navaneedham is expected to give best results for pain and joint inflammation in RA. In modern system of medicine DMRADs are prescribed for Rheumatoid arthritis and also steroids in many cases. 
Karpoora Chindhamani Mathirai would be a better alternative to these drugs.

The rationale behind the selection of Karpoora Chindhamani Mathirai for this preclinical study is that most of the ingredients are used in inflammatory joint diseases and Croton tiglium, Linn., a drastic purgative brings the vatha humour to normal and the purgative action of Croton seeds will be countered my Nutmeg and Gum acacia. So, the medicine is expected to give cure to arthritis patients.

Rasakarpooram (Hydrargyrum subchloride-calomel), one of the major ingredient in the drug is used to cure various types of pain and rheumatism (6). The Siddha traditional preparation Chandamarutha chenduram in which calomel is a major ingredient is found to be very effective in treating post Chikungunya arthritis.(7). The juice of the leaves of Aloe vera is applied to painful inflammation of the body (8). The aqueous extract of Aloe vera inhibited prostaglandin $t 2$ production from arachidonic acid. The aqueous extract has the capacity to inhibit cyclo-oxygenase activity. (9).Aloe vera is also found to be effective against adjuvant induced arthritis.(10). Croton tiglium, Linn. seeds are used in vatha diseases. For rheumatic conditions Croton oil with mustard oil will form a good liniment (11). Myristica fragrans, Houtt is used as a rubefacient and is used as a good liniment for chronic rheumatism (12). Different solvent extract of Myristica fragrans, Houtt possess pharmacological properties like hypocholesteremic, anti-inflammatory, anti-diarrheal etc. The anti-inflammatory activity may be attributed to the active principle Myristicin.(13) Mace, the aril of Myristica fragrans, Houtt also possess anti-inflammatory activity (14 ).

\section{Materials and methods:}

The raw drugs were purchased from authorized dealers from Tambaram and were authenticated by the Head, Department of Gunapadam (Pharmacology) of National Institute of Siddha, Tambaram sanatorium. The raw materials were purified as per the methods mentioned in classic Siddha text. The medicine was prepared as per the methods mentioned in Anuboga Vaidhya Navaneedham (part IV) Hakkeem Pa.Mu Abdulla Sayubu, $1^{\text {st }}$ edition, October 1995, Thamarai noolagam. The animal studies were carried out in C.L.Baid Metha College of Pharmacy, Thuraipakkam, Chennai.

\section{Preparation of the drug Karpoora Chindhamani Mathirai: \\ Ingredients:}

Purified Hydrargyrum subchloride -Rasakarpooram (Calomel) - 17 1/2 G

Purified Myristica fragrans, Houtt (Nutmeg) - Sathikai - 171/2G

Purified Croton tiglium seeds Naervalam (Croton seeds) - 35G

Aloe vera juice - Katralai required quantity.

Acacia indica (gum acacia) powder - Karuvael pisin - 3 1⁄2 G.

\section{Step 1: Purification of raw drugs}

\section{Purification of Calomel:}

The poultice made of betel leaf (Piper betel) and pepper (Piper nigrum) each 8.7 grams is taken in an earthen pot and dissolved in 1.3 lit of water. Calomel $35 \mathrm{gms}$ is tied with a cloth and immersed in the liquid from the cross bar and heated. When the water is reduced to $3 / 4$ of its volume calomel is taken out, washed with water and dried to get it in purified form (15).

\section{Purification of Nutmeg:}

The outer cover is removed and then fried in ghee.

\section{Purification of Croton seeds:}

Croton-35 G

Indian gooseberry fruit juice, Brinjal leaf juice, Cow dung each 20G is 
taken in a vessel and its mouth is closed with a cloth. Croton seeds are placed over the cloth. It is burnt for 3 hours (1samam). Then its tip is removed and the seeds are dried in shade. This procedure is again repeated twice. Then it is fried in cow's ghee (16).

\section{Purification of Aloe gel:}

It is soaked in water for thee days and then used.

Step 2: Method of preparation:

\section{Method:}

Croton seeds and Nutmeg are added to powdered Rasakarpooram and then grounded. Then Aloe vera juice is added to the above mixture in small quantities as and when required. This mixture is grounded for 2 samam (6 hours ). Finally powder of gum acacia is added and grounded. This paste is rolled into pills of $130 \mathrm{mg}$ weight and dried in shade. These dried pills are preserved in a clean wide mouthed glass bottle.

Dosage: 1 tablet (twice a day after food).

Adjuvant: Ghee.

Indications: This medicine is indicated for all types of fever, pain, arthritis and rheumatism (17).

Animal studies:

Preparation of drug for dosing:

Drug used for the study was suspended each time with $1 \%$ (w/v) solution of sodium Carboxy Methyl Cellulose before administration.

\section{Drugs and chemicals:}

All fine chemicals used in this experiment were obtained from Sigma chemicals company, U.S.A. Other analytical grade chemicals were obtained from S.A fine chemicals Ltd., Mumbai. TAB vaccine was obtained from Serum institute, Pune.

\section{Experimental animals:}

Colony inbred animal strains of Wistar rats of either sex weighing 200-
250G were used for the pharmacological and toxicological studies.

Acute oral toxicity study:

Acute oral toxicity study was conducted as per the OECD guidelines (Organization of Economic Cooperation and Development) 423 (acute toxic class method).

Since this formulation is relatively non-toxic in clinical practice the highest dose of $2000 \mathrm{mg} / \mathrm{kg} / \mathrm{po}$ (as per the OECD guidelines "Unclassified") was used in the acute toxicity study.

\section{Repeated oral toxicity study:}

Group 1: Control animals received $1 \% \mathrm{CMC}, 10 \mathrm{ml} / \mathrm{kg} /$ po for 21 days.

Group 2: Suspension of Karpoora Chindhamani Mathirai in CMC at the dose level of $12.5 \mathrm{mg} / \mathrm{kg} / \mathrm{po}$ for 21 days.

\section{Dose for rat:}

\section{$12.5 \mathrm{MG} / \mathrm{KG} / \mathrm{PO}$}

Karpoora Chindhamani Mathirai-

At the end of 21days of treatment all the animals were sacrificed by over dosage of ether anaesthesia. Section of liver, kidney and heart were dissected out and kept in $10 \%$ formalin for histopathological studies.

\section{Biochemical studies:}

Estimation of glucose, AST, ALT, ALP, Urea were done.

\section{Haematological studies:}

Erythrocyte count, WBC, $\mathrm{Hb}$, were studied.

Analgesic, antipyretic and antiinflammatory activity of Karpoora Chindhamani Mathirai:

Analgesic activity:

Hot plate test:

The test was performed using Eddy's hot plate maintained at a temperature of $55 \pm 1{ }^{\circ} \mathrm{C}$. The basal reaction time of all animals was recorded. 
The animals which showed fore paw licking or jumping response within 6-8 secs were selected for the study. $60 \mathrm{~min}$ after the administration of test and reference compounds, the animals in all the six groups were individually exposed to the hot plate maintained at $55^{\circ} \mathrm{C}$. The time taken in secs for fore paw licking or jumping was taken as reaction time. A cut off period of 15 secs is observed to avoid damage to the paws. Analgesic activity was recorded at hourly intervals of 2 hours after drug administration.

\section{Antipyretic activity:}

Rats selected for the study were fasted overnight allowing water $a d$ libitum. Initial rectal temperature was recorded using Hick's clinical thermometer. Pyrexia was induced by subcutaneous injection of TAB vaccine 1 $\mathrm{ml} / \mathrm{kg}$ body weight. Six hours later pyrexia was assessed and those animals that did not show a minimum rise of $1.5^{\circ} \mathrm{C}$ were rejected. The animals thus found fit for the study was divided into 6 groups as described above and drugs were administered. Pyrexia was recorded at hourly intervals for $3 \mathrm{hrs}$ after drug administration..

\section{Anti-inflammatory activity:}

Anti-inflammatory activity of Karpoora Chindhamani Mathirai was evaluated in both acute and chronic models of inflammation.

\section{Acute model:}

Carrageenin induced hind paw oedema ( Winter et al 1962).

\section{Chronic model:}

Cotton pellet granuloma (Swingle and Svidem an et al;1972).

\section{Statistical analysis:}

Students paired T-test is used for analyzing $\mathrm{Hb}$, Markers of liver and kidney and antipyretic activity. One way
ANOVA-Dunnett's multiple comparison test is employed in assessing the analgesic and anti-inflammatory activity.

Results and discussion:

Acute oral toxicity study:

Karpoora Chindhamani Mathirai at the dose of $2000 \mathrm{mg} / \mathrm{kg} / \mathrm{po}$ did not exhibit any mortality in rats. As per OECD 423 guidelines the dose is said to be "unclassified "under the toxicity scale. Here further study with higher doses was not executed.

\section{Repeated oral toxicity study for $\mathbf{2 1}$ days:}

The test drug Karpoora Chindhamani Mathirai at the dose of $12.5 \mathrm{mg} / \mathrm{kg} / \mathrm{po}$ when administered orally for 21 days in rats did not show toxicity in liver and renal functions.21 days repeated dosing of the drug did not exhibit change in serum glucose and cholesterol levels.

\section{Biochemical studies:}

There was no significant change in glucose level, AST, ALT, ALP and Urea levels when compared to control.

\section{Haematological studies:}

There was no significant change in Erythrocyte count, WBC and Haemoglobin count.

\section{Histopathological study:}

Karpoora Chindhamani Mathirai at the dose of $12.5 \mathrm{mg} / \mathrm{kg} / \mathrm{po}$ daily administration for 21 days did not show evidence of pathological lesions in the tissues tested.

Analgesic, Antipyretic studies:

Anti-inflammatory, Karpoora Chindhamani Mathirai exhibited significant anti-inflammatory activity in both carrageenin induced hind paw (acute inflammation model) and cotton pellet granuloma (chronic inflammation model) model of inflammation in rats. The results of the 
present study was comparable to that of the standard NSAID Diclofenac sodium $(5 \mathrm{mg} / \mathrm{kg} / \mathrm{po})$. (Table 1,2$)$.
Karpoora Chindhamani Mathirai at the dose of $12.5 \mathrm{mg} / \mathrm{kg} /$ po showed significant analgesic, antipyretic activity in rats.

Table 1:

Anti-inflammatory activity of Karpoora Chindhamani Mathirai in carrageenin induced hind paw edema in rats:

\begin{tabular}{|c|c|c|c|c|c|}
\hline Groups & Paw volume & nl) by Mercur & displacemen & it regular inte & al of time \\
\hline & Omin & 30min & 60min & $120 \mathrm{~min}$ & $240 \mathrm{~min}$ \\
\hline $\begin{array}{l}\text { Test } \\
\text { Karpoora } \\
\text { Chindhaman } \\
\text { i Mathirai }\end{array}$ & $0.901 \pm 0.034$ & $1.0961 \pm 0.77$ & $\begin{array}{l}0.9781 \pm 0.04 \\
4\end{array}$ & $1.381 \pm 0.12 * *$ & $\begin{array}{l}01.22 \pm 0.017 * \\
*\end{array}$ \\
\hline $\begin{array}{l}\text { Standard } \\
\text { (Dic.sodium } \\
5 \mathrm{mg} / \mathrm{kg} / \mathrm{po} \text { ) }\end{array}$ & $\begin{array}{l}0.883 \pm 0.63 * \\
*\end{array}$ & $\begin{array}{l}0.996 \pm 0.067 * \\
*\end{array}$ & $\begin{array}{l}1.02 \pm 0.064 * \\
*\end{array}$ & $\begin{array}{l}0.926 \pm 0.041^{*} \\
*\end{array}$ & $0.896 \pm 0.026$ \\
\hline
\end{tabular}

Table 2:

Anti-inflammatory activity of Karpoora Chindhamani Mathirai in cotton pellet granuloma:

\begin{tabular}{|l|l|}
\hline Groups & $\begin{array}{c}\text { Cotton pellet granuloma method } \\
\text { Dry wt(mg) }\end{array}$ \\
\hline Control Karpoora Chindhamani & $115.87 \pm 15.42$ \\
\hline $\begin{array}{l}\text { Test } \\
\text { Mathirai }\end{array}$ & $76.00 \pm 10.32^{* *}$ \\
\hline Standard (Dic.sodium 5mg/kg/po) & $70.00 \pm 7.42^{* *}$ \\
\hline
\end{tabular}

\section{Discussion:}

The Siddha formulation was tested for its reverse pharmacological and toxicological profiles in the experimental rats. The drug did not exhibit any mortality at the dose of $2000 \mathrm{mg} / \mathrm{kg} / \mathrm{po}$ and hence it is safe to be used in humans. The repeated oral toxicity also did not exhibit any change in haematological parameters. The test drug exhibited significant analgesic, antipyretic and anti-inflammatory activity in both acute and chronic experimental inflammatory condition in rats. The anti- inflammatory activity was comparable to Diclofenac sodium $(5 \mathrm{mg} / \mathrm{kg} / \mathrm{po})$. Hence the drug will be clinically effective in inflammatory arthritis. The antiinflammatory activity can be attributed to the ingredients Rasakarpooram and Aloe vera. In Rheumatoid arthritis inflammation of major and minor joints is very common and so this drug can be tried for RA patients. The test drug showed maximum anti-inflammatory activity at the end of $4^{\text {th }}$ hour after carrageenin challenge. The mechanism of anti-inflammatory activity 
of the test drug may be attributed to its inhibitory activity on cyclooxygenase (COX) enzymes.

\section{Conclusion:}

The drug Karpoora Chindhamani Mathirai in classic Siddha test exhibited no toxicity pre clinically. It also showed significant anti-inflammatory, analgesic and antipyretic activity. Hence the efficacy of this drug can be tested clinically in future.

\section{Acknowledgements:}

The authors wish to acknowledge the Director of C.L.Baid Metha College of Pharmacy, Thuraipakkam, Chennai for his guidance in pharmacological studies. The authors also express their sincere thanks to Dr.S.Kannan for his valuable guidance in the trial drug preparation.

\section{References :}

1.http;//www.medicinenet.com/rheumatoid arthritis/article.htm.

2. Yugi Mamunivar. Yugi Vaidhya Chindhamani. $2^{\text {nd }}$ ed. Department of Indian medicine and Homoeopathy,Chennai-47; 2005.77p, Verse-319.

3.Malaviya A.N,.Kapoor S.K,.Singh R.R,.Kumar and I.Pande. Prevalence of $\mathrm{RA}$ in adult Indian population. Rheumatology International.1993; 3(4); 131-134.

4.Malaviya A.N, Singh R.R, Kapoor S.K, Kumar A, Singh Y.N. Prevalence of rheumatic disease in India. Journal of Indian Rheumatism association. JanMar,1994; 2(L); 13-17.

5.Fact Sheet no.134: Traditional Med. WHO. 2008-12-01, Retrived 2009-0502.

6,15.Dr..Thyagarajan R. Siddha Materia Medica,(Mineral and Animal kingdom), $1^{\text {st }}$ ed . Department of Indian medicine and Homoeopathy,Chennai-47;2008. 234,235 .

7.Management of Chikungunya through Ayurveda and Siddha- a technical report. Central Council for Research in Ayurveda and Siddha, Department of AYUSH, New Delhi;2009. 103p.

8,11,12.Dr..Nudkarni K.M.Indian Materia Medica (Volume- 1). $3^{\text {rd }}$ revised and enlarged ed., Popular Prakashan Pvt.Ltd;. 1954, Reprint 2005. 76p,398397p, 833p.

9.Beatriz Vazquez, Guillermu Avila, David Segura, Bruno Escalance. Antiinflammatory activity of extracts from Aloe vera gel. Journal of ethnopharmacology.Dec,1996; 155(1); 69-75.

10.Davis R.H, Shapiro.E and Agrew, P.S. Biological activity of Aloe vera.J.Am.Pod.Assoc. 1985; 75(1); 229237.

13.Mohd Abdul Rasheed Naikodi, Mohd Abdul Waheed, Mohammed Ataullah Shareef,Mustaq Ahmed, Kommu Naga. Standardization of the Unani drugMyristica fragrens Houtt. with modern analytical techniques. Pharmaceutical methods .2011; 2(2); 76-82.

14.Ozaki Y, Soedigdo S, Wattimena Y R, Suganda A G.Anti-inflammatory effect of Mace, aril of Myristica fragrens Houtt, and its active principles. Jpn.J.Pharmacol. Feb, 1989 ;49(2); 155163.

16.Dr.Murugesa Mudhaliyar. Gunapadam Mooligai vaguppu (Part-1). $7^{\text {th }}$ ed.Indian medicine and Homoeopathy Department,Chennai-47;626p.

17.Hakeem Abdulla Sayabu. Anuboga Vaidhya Navaneedham (Part 4). $1^{\text {st }}$ ed.Thamarai noolagam; 106p. 